\title{
ANALISIS KELAYAKAN EKONOMIS CLOUD COMPUTING PADA LEMBAGA KEUANGAN MIKRO DI INDONESIA DENGAN METODE RANTI'S GENERIC IS/IT BUSINESS VALUE DAN ECONOMIC VALUE ADDED: STUDI KASUS PADA BANK PERKREDITAN RAKYAT DI JAKARTA
}

\author{
Pamela Darmadji dan Benny Ranti
}

Fakultas Ilmu Komputer, Universitas Indonesia, Kampus UI Depok, Jawa Barat, 16424, Indonesia

E-mail: pamela.a01@ui.co.id

\begin{abstract}
Abstrak
Bank Perkreditan Rakyat (BPR) sebagai salah satu pemain terbesar dalam bisnis keuangan mikro di Indonesia telah meningkatkan penggunaan Sistem Informasi/Teknologi Informasi (SI/TI) untuk mendukung bisnis mereka. Namun, hanya sedikit dari mereka yang menyadari isu-isu seputar investasi TI. Ada kekhawatiran tentang tidak tersedianya sumber daya yang cukup untuk membeli, memelihara, dan mengamankan SI/TI mereka sendiri. Di sisi lain, investasi yang besar diperlukan dan akhirnya menjadi momok bagi BPR yang paling menerapkan SI/TI untuk mendukung pengembangan bisnis mereka. Penelitian ini menganalisis nilai ekonomi dari penerapan komputasi awan di BPR. Analisis dilakukan, pertama dengan mengidentifikasi dan mengukur relevansi manfaat SI/TI menggunakan Ranti's IS/IT Generic Business Values dan kedua dengan menempatkan nilai-nilai yang diukur atau manfaat pada metode Economic Value Added (EVA), untuk melakukan analisis keuangan. Komputasi awan mampu memberikan solusi bagi masalah yang dihadapi oleh BPR seperti dapat dilihat dari nilai EVA positif. Oleh karena itu, komputasi awan merupakan pendekatan yang berharga bagi BPR untuk bergerak maju. Resiko investasi SI/TI dapat ditransfer ke penyedia komputasi awan, dengan kata lain, tidak ada waktu untuk berpikir tentang teknologi usang sebelum Return of Investment (ROI) tercapai.
\end{abstract}

Kata Kunci: Bank Perkreditan Rakyat, investasi SI/TI, komputasi awan, nilai bisnis SI/TI, rural banks

\begin{abstract}
Abtract
Bank Perkreditan Rakyat (BPR) as one of the biggest players in Indonesia's microfinance business has increased their use of Information Systems/Information Technology (IS/IT) to support their business. However, only few of them are aware of issues around IT investment. There are concerns about the unavailability of sufficient resource to purchase, maintain, and secure their own IS/IT. On the other hand, a large investment is needed and it eventually becomes the scourge for most rural banks to apply IS/IT to support their business development. This research analyzes the economic value of implementing cloud computing in BPR. Analysis is done, firstly by identifying and quantifying the relevant IS/IT benefits using Ranti's IS/IT Generic Business Values and, secondly by putting the quantified values or benefits into Economic Value Added (EVA) method to do the financial analysis. Cloud computing is able to provide solutions for problems faced by BPR as can be seen from the positive EVA value. Hence, the cloud computing is a valuable approach for BPR to move forward. IS/IT investment risk can be transferred to cloud computing providers, in other words, there is no time to think about outdated technology before Return of Investment (ROI) is achieved.
\end{abstract}

Keywords: Bank Perkreditan Rakyat, cloud computing, IS/IT business value, IS/IT investment, rural banks,

\section{Pendahuluan}

Bank Prekreditan Rakyat merupakan salah satu jenis bank yang melayani golongan pengusaha mikro, kecil, dan menengah. Hal ini membuat Bank Perkreditan Rakyat tidak lepas dari tuntutan untuk mengembangkan keuangan mikro di Indonesia. Kondisi yang ada saat ini adalah banyak Bank Perkreditan Rakyat di
Indonesia yang masih belum menggunakan teknologi yang ada untuk membantu proses bisnisnya, sehingga Bank Perkreditan Rakyat memiliki keterbatasan dalam mewujudkan tujuannya yaitu untuk membantu memajukan keuangan mikro di Indonesia. Total Bank Perkreditan Rakyat tercatat pada bulan Juli 2010 adalah sebanyak 1767 bank yang tersebar diseluruh wilayah Indonesia, dan dengan jumlah 
akun sebanyak 2.929.702 (diambil dari data statistik Bank Indonesia, 2010).

Solusi yang cukup murah dan efisien pada penerapan TI pada Bank Perkreditan Rakyat untuk dapat menunjang aktivitasnya saat ini adalah dengan pengimplementasian cloud computing. Layanan cloud computing ini tergolong cukup murah karena layanan ini menggunakan mekanisme economies of scale, dimana semakin banyak yang ikut menggunakan layanan tersebut, maka semakin baik dan murah. Layanan yang ditawarkan misalnya meliputi Infrastructure as a Service (IaaS), Platform as a Service (PaaS), dan Software as a Service (SaaS). Sebagai contoh, aplikasi cloud computing berbasis PAAS, yaitu e-UKM, dimana aplikasi ini digunakan oleh Bank Perkreditan Rakyat sebagai sistem pengelolaan koperasi pendidikan dan lainnya.

Penelitian ini mengambil studi kasus pada Bank Perkreditan Rakyat karena beberapa alasan diantaranya, Bank Perkreditan Rakyat memegang peranan yang cukup besar bagi perekonomian Indonesia, Bank Perkreditan Rakyat memiliki sistem yang lebih kompleks dibandingkan dengan Lembaga Keuangan Mikro (LKM) lain (misalnya memiliki tabungan, dimana LKM lain tidak memiliki layanan tabungan), Bank Perkreditan Rakyat memiliki tabungan dan akun bank untuk rakyat, sehingga akan lebih memudahkan dalam mengelola sistem, sudah terdapat regulasi yang jelas mengenai Bank Perkreditan Rakyat, dan walaupun jumlah Bank Perkreditan Rakyat yang cukup banyak dan tersebar di seluruh wilayah Indonesia, namun tetap memiliki karakteristik yang sama.

Investasi merupakan hal yang harus dilakukan oleh sebuah perusahaan, terutama pada saat bisnisnya sedang berada dalam tahap pembentukan dan pertumbuhan. Penilaian investasi TI merupakan kemampuan organisasi dalam mengidentifikasi dan mengkuantifikasi peningkatan keuntungan atau dampak positif yang diterima perusahaan dengan adanya implementasi TI dalam operasi bisnis perusahaan tersebut [1].

Pada sektor perbankan dan keuangan, total biaya TI adalah $10,6 \%$ dari keseluruhan pendapatan perusahaan [2]. Sekarang ini para CEO dan manajemen TI tidak lagi fokus dalam pembiayaan TI, tetapi lebih kepada investasi TI yang dapat memberikan andil dalam perkembangan bisnis perusahaan.

Keuangan mikro dalam bahasa Inggris disebut sebagai Microfinance, yang berasal dari kata "micro enterprise" yaitu usaha mikro, dan "finance" yang berarti pembiayaan. Dari kedua istilah tersebut, dapat diartikan bahwa microfinance berarti pembiayaan untuk usaha mikro. Usaha mikro sendiri adalah suatu bisnis yang dijalankan dengan skala kecil, dimana volume usaha (omset) tidak melebihi Rp 100 juta per tahun dan modal kerja yang dimiliki tidak lebih dari Rp 25 juta. Usaha mikro ini biasanya tidak memiliki legalitas usaha, sehingga tidak terakses oleh bank.

Keuangan mikro merupakan perbankan yang tidak memiliki bank, dengan membawa kredit, tabungan, atau bentuk keuangan lainnya seadanya, jutaan orang yang sangat miskin dapat dilayani oleh bank [3].

Dalam definisi Bank Indonesia, Bank Perkreditan Rakyat adalah salah satu jenis bank yang dikenal melayani golongan pengusaha mikro, kecil, dan menengah dengan lokasi yang pada umumnya dekat dengan tempat masyarakat yang membutuhkan. Fungsi Bank Perkreditan Rakyat tidak hanya sekedar menyalurkan kredit kepada pengusaha mikro, kecil, dan menengah, namun juga menerima simpanan atau tabungan dari masyarakat.

Terkait dengan investasi TI pada Bank Perkreditan Rakyat, beberapa penyedia jasa TI kini bekerja sama untuk melakukan kajian dan analisis bisnis proses Bank Perkreditan Rakyat dan kebutuhannya akan teknologi yang cocok bagi Bank Perkreditan Rakyat. Hasil analisis kebutuhan Bank Perkreditan Rakyat akan teknologi menunjukkan adanya kebutuhan dari sisi core banking system, Channel System, Payment Points \& Collection, dan Management Information System (MIS) [4].

Cloud computing merupakan bentuk online dari grid computing dan merupakan penerapan konsep komputasi terdistribusi yang lebih diarahkan pada jaringan internet [5][6]. Cloud computing kini merupakan istilah umum untuk segala sesuatu yang melibatkan jasa ter-host melalui internet [7].

Terdapat tiga macam pemodelan layanan dari cloud computing yaitu infrastructure as a service (IaaS), platform as a service (PaaS), dan software as a service (SaaS). Pada IaaS, beberapa server yang diletakkan dalam cloud dengan alamat IP yang unik dan sejumlah harddisk untuk menyimpan data. Pengguna menggunakan Application Program Interface (API) untuk dapat mengakses, menyalakan dan mematikan, serta mengkonfigurasi virtual server dan harddisk. PaaS pada cloud didefinisikan sebagai perangkat lunak yang terhubung pada infrastruktur penyedia jasa layanan cloud computing. 


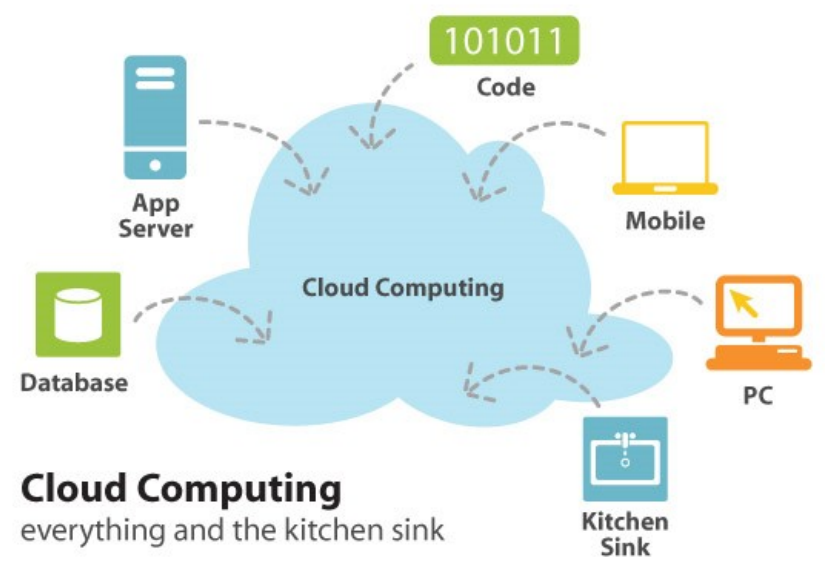

Gambar 1. Cloud computing.

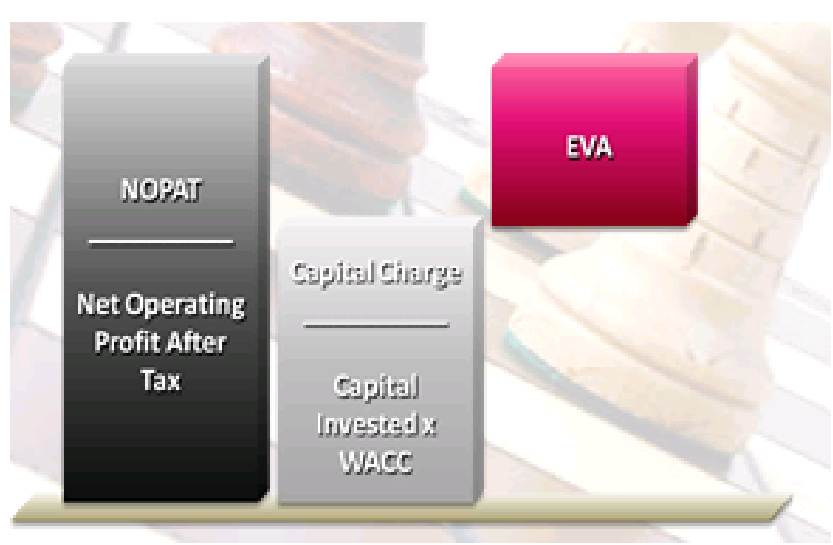

Gambar 2. Deskripsi EVA.

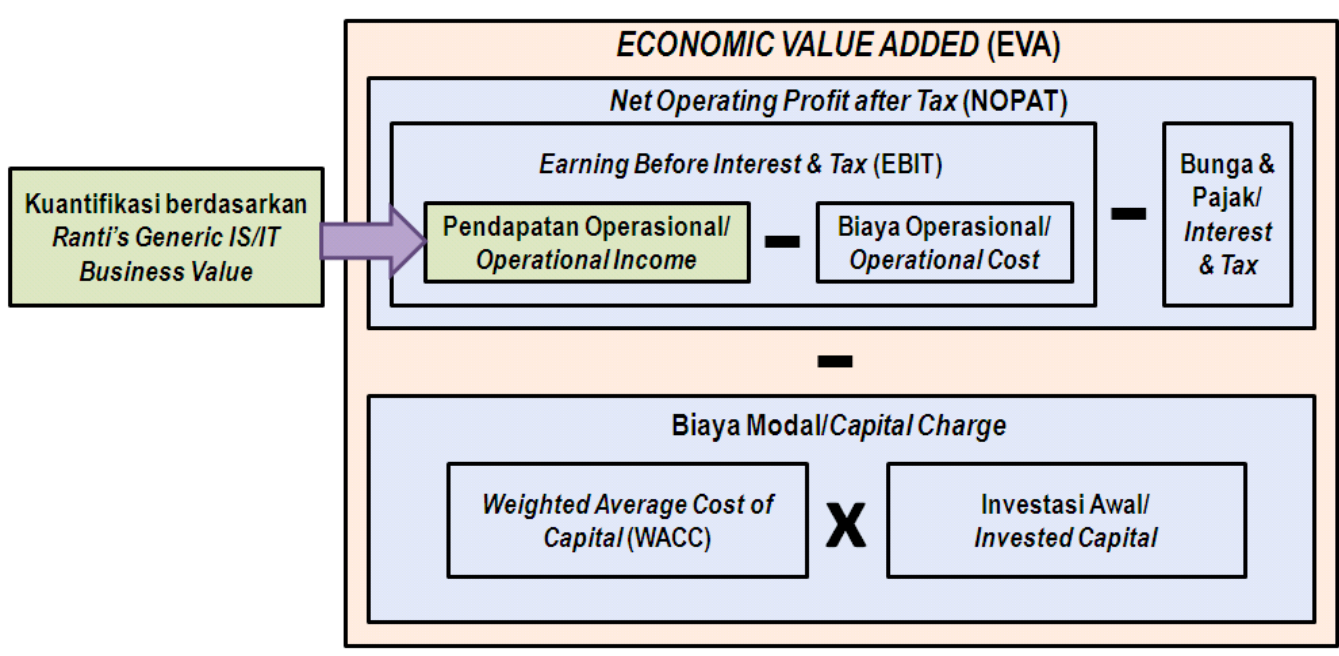

Gambar 3. Penerapan Ranti's IS/IT generic business value dengan metode EVA.

Contohnya adalah force.com dan GoogleApps. Pada SaaS, penyedia jasa memasok infrastruktur berupa perangkat keras, produk perangkat lunak, dan berhubungan dengan pengguna melalui portal front-end. SaaS memiliki pasar yang sangat luas. 


\section{Metodologi}

Ranti's Generic IS/IT Business Value merupakan kerangka yang digunakan untuk mengidentifikasikan manfaat-manfaat yang dapat diperoleh dari suatu investasi TI tanpa perlu membedakan antara manfaat tangible dan intangible yang selama ini sering menjadi penghambat dalam pengkuantifikasian manfaat TI. Dengan menggunakan metode kualitatif hermeneutic, nilai manfaat bisnis IS/IT dikelompokkan menjadi 13 kategori yang kemudian dikelompokkan lagi menjadi 73 subkategori [8].

Metode EVA merupakan salah satu pengukur kinerja perusahaan yang mencoba mengukur nilai tambah yang dicapai perusahaan yang dihitung dengan cara mengurangi biaya modal dari laba usaha setelah pajak sebelum beban bunga (net operating after tax) [9].

Metodologi EVA digunakan untuk mengukur tingkat kelayakan finansial dalam investasi TI yang akan dilakukan. Pengukuran EVA yang positif menandakan bahwa investasi tersebut memberikan nilai bagi perusahaan. Sebaliknya, nilai EVA yang negatif menunjukkan bahwa nilai perusahaan menurun karena tingkat pengembalian investasi tersebut yang rendah dibanding dengan modal yang dikeluarkan, atau bahkan merugi.

Penelitian ini menerapkan kedua metode Ranti's Generic IS/IT Business Value dan EVA. Hasil perhitungan kuantifikasi yang didapat melalui Ranti's Generic IS/IT Business Value akan menjadi masukan pada perhitungan nilai EVA. Hal ini digambarkan pada Gambar 3. Selain itu dilakukan juga suatu analisis tambahan yang berguna untuk mendukung hasil yang didapat dari perhitungan dengan menggunakan metodologi sebelumnya. Baik dari perbandingan nilai investasi maupun perbandingan nilai EVA.

\section{Hasil dan Pembahasan}

Pengimplementasian investasi cloud computing pada Bank Perkreditan Rakyat yang dilakukan meliputi jenis IaaS dan SaaS. Untuk implementasi awal Bank Perkreditan Rakyat tidak perlu melakukan apa pun, dengan asumsi secara infrastruktur, Bank Perkreditan Rakyat sudah memiliki koneksi internet.

Implementasi ini memungkinkan beberapa Bank Perkreditan Rakyat untuk terkoneksi ke cloud yang sama. Pola pemikiran jangka panjangnya adalah untuk mengintegrasikan beberapa Bank Perkreditan Rakyat dalam satu lokasi (misalnya) dimana nantinya terdapat Bank Payung yang memayungi setiap Bank Perkreditan
Rakyat tersebut, serta membantu Bank Perkreditan Rakyat dalam kegiatan operasionalnya.

Dari hasil analisis dan wawancara dengan pihak Bank Perkreditan Rakyat, dari 73 manfaat yang ada dalam Ranti's Generic IS/IT Business Value, terdapat 39 manfaat yang relevan terhadap pengimplementasian cloud computing pada Bank Perkreditan Rakyat. Beberapa manfaat yang bersifat redundan dan memiliki kriteria yang sama dapat memiliki perhitungan kuantifikasi yang sama. Manfaat-manfaat tersebut kemudian dikelompokkan menjadi enam kategori manfaat, dimana pembagian kategori manfaat dilakukan berdasarkan kuantifikasi dari masing-masing manfaat yang diidentifikasikan.

Keenam kategori manfaat tersebut adalah peningkatan pendapatan karena peningkatan mutu layanan, peningkatan pendapatan karena minimalisasi resiko keterlambatan pengumpulan laporan ke BI, peningkatan pendapatan karena minimalisasi resiko piutang tak tertagih,p eningkatan pendapatan karena peningkatan kualitas laporan, peningkatan pendapatan karena peningkatan kapasitas bisnis, serta peningkatan pendapatan karena minimalisasi biaya operasional.

Kuantifikasi dilakukan dengan memperhitungkan fakta, informasi, dan asumsi yang bisa diambil dari hasil wawancara dan diskusi dengan nara sumber. Perhitungan dibagi menjadi dua, yaitu kualitatif, untuk perhitungan yang saat ini belum bisa dihitung secara kuantitatif karena faktor keterbatasan waktu maupun tingkat kompleksitas yang tinggi, dan kuantitatif, perhitungan nilai manfaat.

Tabel I menunjukkan hasil kuantifikasi manfaat untuk keenam kategori manfaat yang telah diidentifikasikan dan total manfaat yang didapat.

Untuk implementasi cloud computing, tidak ada investasi awal yang harus dikeluarkan oleh Bank Perkreditan Rakyat. Syarat utamanya hanya koneksi jaringan internet yang stabil untuk dapat terhubung dengan jaringan cloud penyedia jasa. Sedangkan koneksi internet sudah terpasang sebelumnya sehingga tidak lagi diperlukan investasi awal untuk jaringan.

Biaya operasional merupakan asumsi biaya operasional sehari-hari setelah dilakukan investasi. Asumsi diambil berdasarkan rata-rata biaya operasional yang dikeluarkan oleh Bank Perkreditan Rakyat dikurangi total rata-rata persentase penurunan biaya karena adanya arsitektur cloud computing. Total biaya operasional Bank Perkreditan Rakyat adalah sebesar Rp 977,118,833,-. 


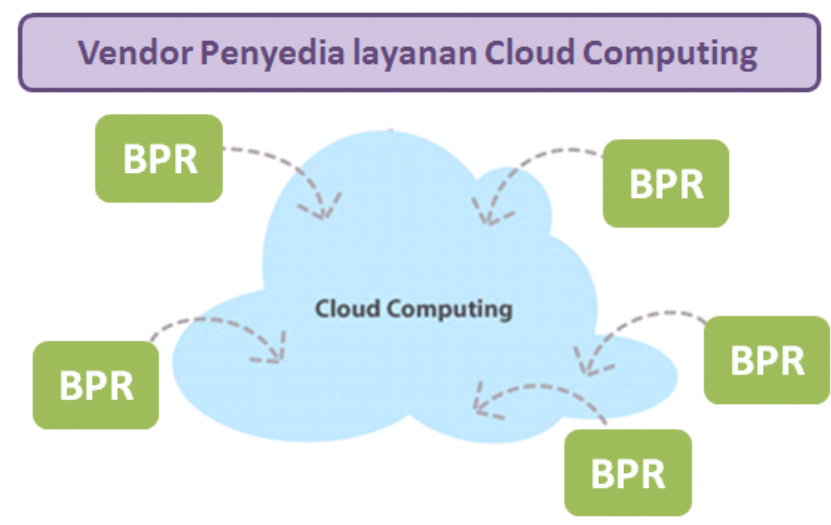

Gambar 4. Cloud computing pada Bank Perkreditan Rakyat.

TABEL I

Total Nilai ManfaAt ImPlementasi CLOUD COMPUTING PADA BANK PERKREDITAN RAKyat

\begin{tabular}{lr}
\hline \multicolumn{1}{c}{ Kuantifikasi Manfaat } & \multicolumn{1}{c}{ (Rp) } \\
\hline Meningkatkan produktivitas karena proses transaksi yang lebih cepat & $30,000,000$ \\
Meningkatkan pelayanan eksternal. mutu layanan. dan keunggulan kompetitif & $6,294,936$ \\
Peningkatan Pendapatan Karena Minimalisasi Resiko Keterlambatan Pengumpulan Laporan ke BI & $1,250,000$ \\
Peningkatan Pendapatan Karena Minimalisasi Resiko Piutang Tak Tertagih & $514,634,577$ \\
Peningkatan pendapatan karena minimalisasi resiko kehilangan karyawan potensial & $35,250,000$ \\
Manfaat Peningkatan Pendapatan Karena Peningkatan Kapasitas Bisnis & $295,000,000$ \\
Manfaat Peningkatan Pendapatan Karena Minimalisasi Biaya Operasional & $174,064,000$ \\
\hline TOTAL Nilai Manfaat & $1,056,493,513$ \\
\hline
\end{tabular}

Dari perhitungan sebelumnya, maka didapat nilai EBIT adalah mengurangi pendapatan operasional dengan biaya operasional, sehingga pada persamaan 1:

$$
\begin{aligned}
& \mathrm{EBIT}=\mathrm{Rp} 1.056 .493 .513,--\mathrm{Rp} 977.118 .833,- \\
& \quad=\operatorname{Rp} 79.374 .680,-
\end{aligned}
$$

Perhitungan NOPAT didapat dari nilai EBIT dikurangi pajak. Pajak yang harus dibayarkan oleh Bank Perkreditan Rakyat setiap tahun adalah sebesar 25\% (data diambil sesuai dengan peraturan Bank Indonesia dan angka yang disebutkan dari proses wawancara), sehingga perhitungan NOPAT-nya pada persamaan 2 adalah:

$$
\begin{aligned}
& \text { NOPAT }=\text { Rp79.374.680,- }-(\operatorname{Rp} 79.374 .680,- \\
& \text { *25\%) } \\
& \quad=\text { Rp 59.531.010,- }
\end{aligned}
$$

Karena nilai investasi terhadap cloud computing untuk Bank Perkreditan Rakyat tidak ada, maka nilai WACC tidak perlu dicari, karena berapa pun dikalikan dengan nol, hasilnya akan nol, sehingga, perhitungan EVA pada persamaan 3 adalah:

$$
\begin{aligned}
\text { EVA } & =\text { NOPAT }-(\text { WACC } * \text { Invested Capital }) \\
& =\operatorname{Rp} 59.531 .010,-(\text { WACC } * 0) \\
& =\operatorname{Rp} 59.531 .010,-
\end{aligned}
$$

Analisis perbandingan investasi ini dilakukan sebagai analisis tambahan untuk mendukung analisis manfaat dan perhitungan EVA yang sudah dilakukan dalam mengkaji manfaat ekonomis investasi sistem cloud computing. Perbandingan dilakukan dengan dua skenario. Skenario A, Bank Perkreditan Rakyat melakukan investasi infrastruktur biasa (client server). Skenario B, Bank Perkreditan Rakyat melakukan investasi cloud computing.

Setiap skenario terdiri dari dua bagian besar yaitu nilai investasi yang harus ditanamkan dan biaya pemeliharaan (maintenance) yang harus dikeluarkan selama lima tahun setelah investasi dilakukan. Perhitungan dihitung secara detil dengan memperhitungkan asumsi 30\% untuk biaya pemeliharaan pada tahun pertama, dan $25 \%$ untuk biaya pemeliharaan untuk tahun-tahun berikutnya.

Harga cloud computing sendiri seharga \$11 per akun, dengan perhitungan nilai kurs sebesar Rp 8.900,-, sehingga nilainya dalam rupiah adalah sebesar Rp 97.900,--. Rincian perbandingan nilai investasi pada skenario A dan B dapat dilihat pada tabel II. 
100 Jurnal Sistem Informasi, Volume 7, Nomor 2, Oktober 2011

TABEL II

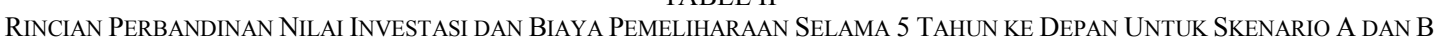

\begin{tabular}{|c|c|c|}
\hline Skenario & Biaya (Rp) & Jumlah akun \\
\hline \multicolumn{3}{|l|}{ Skenario A } \\
\hline Inisial Investasi: & $652,440,000$ & 1,658 \\
\hline \multicolumn{3}{|l|}{ Biaya Pemeliharaan: } \\
\hline - Tahun 1 & $195,732,000$ & 1,658 \\
\hline - Tahun 2 & $200,625,300$ & 1,721 \\
\hline - Tahun 3 & $205,640,933$ & 1,786 \\
\hline - Tahun 4 & $210,781,956$ & 1,853 \\
\hline - Tahun 5 & $216,051,505$ & 1,923 \\
\hline \multicolumn{3}{|l|}{ Skenario B } \\
\hline Inisial Investasi & Tidak ada & 1,658 \\
\hline \multicolumn{3}{|l|}{ Biaya Pemeliharaan: } \\
\hline - Tahun 1 & $162,318,200$ & 1,658 \\
\hline - Tahun 2 & $168,453,828$ & 1,721 \\
\hline - Tahun 3 & $174,821,383$ & 1,786 \\
\hline - Tahun 4 & $181,429,631$ & 1,853 \\
\hline - Tahun 5 & $188,287,671$ & 1,923 \\
\hline
\end{tabular}

TABEL III

BiaYa PEMELIHARAAN PER AKUn DALAM JANGKa WAKTU Lima TAHUN SETELAH IMPLEMENTASI

\begin{tabular}{lccc} 
& BIAYA PEMELIHARAAN PER AKUN DALAM JANGKA WAKTU LIMA TAHUN SETELAH IMPLEMENTASI \\
\cline { 2 - 4 } & \multirow{2}{*}{ Tahun } & \multicolumn{2}{c}{ Biaya permeliharaan per akun (Rp) } \\
\cline { 2 - 4 } Tahun ke 1 & & 118,053 & Skenario B \\
Tahun ke 2 & 116,597 & 89,000 \\
Tahun ke 3 & 115,159 & 89,000 \\
Tahun ke 4 & 113,739 & 89,000 \\
Tahun ke 5 & 112,336 & 89,000 \\
\hline
\end{tabular}

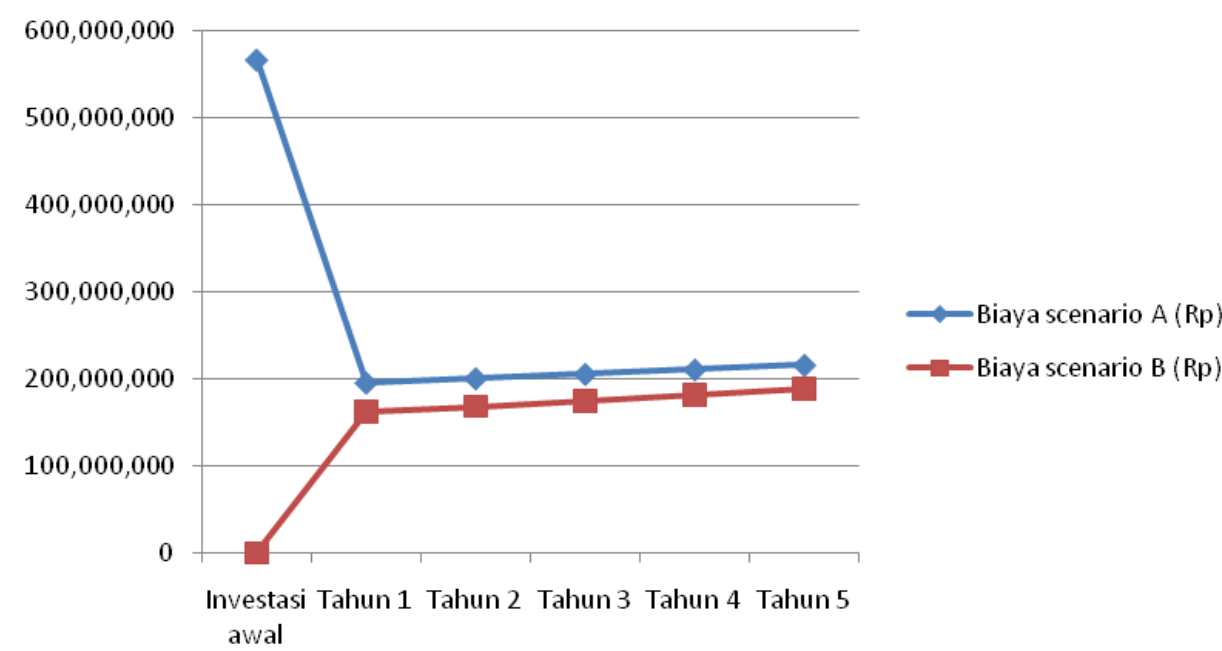

Gambar 5. Grafik biaya skenario A dan B.

TABEL IV

Perbandingan Perhitungan Nilai EVA Skenario A dan B

\begin{tabular}{|c|c|}
\hline Perhitungan EVA Skenario A & Perhitungan EVA Skenario B \\
\hline $\begin{array}{c}\text { NOPAT }=(\text { Pendapatan operasional }- \text { Biaya operasional })-\text { Pajak } \\
=\text { Rp. } 1.167 .948 .167-\text { Rp. } 977.118 .833=\text { Rp. } 190.829 .333 \\
\text { WACC } \times \text { Invested } \text { Capital }=\text { Rp. } 652.440 .000\end{array}$ & $\begin{array}{c}\text { NOPAT }=(\text { Pendapatan operasional }- \text { Biaya operasional })-\text { Pajak } \\
=\text { Rp. } 1.056 .493 .513-\text { Rp. } 977.118 .833=\text { Rp. } 79.374 .680\end{array}$ \\
NOPAT - Invested Capital $=$ Rp. -461.610 .667 & WACC $\times$ Invested Capital $=$ Rp. 0
\end{tabular}


Pada skenario A, tren biaya pemeliharaan secara nominal semakin besar, namun jika dibandingkan dengan jumlah biaya yang semakin meningkat, hal ini membuat infrastruktur yang telah diimplementasi semakin ekonomis. Hal ini diperjelas pada tabel III yang menunjukkan bahwa harga infrastruktur per akun dalam jangka waktu lima tahun setelah implementasi. Sedangkan pada skenario B, biaya meningkat seiring dengan meningkatnya jumlah akun, namun tetap pada nilai yang sama. Hal ini menjadikan skenario $B$ sudah ekonomis sejak pertama kali diimplementasi. Biaya pemeliharaannya pun lebih kecil dibandingkan dengan skenario A walaupun perbedaannya tidak terlalu signifikan.

Analisis perbandingan juga dilakukan untuk membandingkan nilai EVA terhadap masingmasing skenario. Gambar 5 dan table IV menunjukkan perbandingan perhitungan EVA terhadap skenario A dan skenario B. Berdasarkan hasil perhitungan. Nilai EVA pada skenario B lebih tinggi dibandingkan dengan nilai EVA pada skenario A, hal ini menunjukkan bahwa investasi pada skenario B lebih ekonomis dibandingkan dengan investasi pada skenario A.

Hasil analisis ini memperkuat gagasan bahwa implementasi cloud computing memang memiliki manfaat lebih bagi Bank Perkreditan Rakyat dan layak untuk di implementasi.

\section{Kesimpulan}

Pengkombinasian metode EVA dan Ranti's Generic IS/IT Business Value's Generic IS/IT Business Value sangat memudahkan dalam melakukan kajian manfaat ekonomis dari suatu investasi TI. Untuk kerangka acuan bagi implementasi cloud computing pada BPR, didapat 39 manfaat yang relevan dan menghasilkan enam kategori manfaat besar. Hasil kuantifikasi yang didapat sebesar Rp 1.056.493.513,-- kemudian menjadi masukan untuk salah satu komponen dalam perhitungan dalam metode EVA. Dikalkulasi dengan komponen EVA lainnya sesuai dengan rumus EVA, maka didapat nilai EVA adalah sebesar Rp 59.531.010,-- Hasil EVA yang positif menandakan bahwa implementasi tersebut dapat memberikan profit bagi perusahaan jika dijalankan. Dari hasil yang didapat pada analisis perbandingan, terlihat bahwa walaupun kedua investasi tersebut sama-sama ekonomis, namun nilai sistem cloud computing tetap lebih ekonomis daripada investasi infrastruktur biasa. Dari hasil yang didapat melalui perhitungan kuantifikasi Ranti's Generic IS/IT Business Value, EVA, dan analisis perbandingan, dapat dilihat bahwa implementasi cloud computing layak untuk diterapkan pada Bank Perkreditan Rakyat.

\section{Referensi}

[1] B. Ranti, "A Review of Information Tecnology Investment Evaluation Methodologies: The Need for Appropriate Evaluation methods" In Proceeding of ICT Journal the Indonesia ICT Institute, pp. 112115, 2006.

[2] B. Ranti, "Introduction to IS/IT Investment Valuation," Rev.2.2/BR/X/2010, Ph.D Thesis, Magister of Information Technology, Faculty of Computer Science, Universitas Indonesia, Indonesia, 2010.

[3] G. van Maanen, "Microcredit: Sound Business or Development Instrument," Oikocredit, Netherland, 2004.

[4] XYZ Foundation, Indonesia Microfinance MIS Requrements Study, Laporan Penelitian, Jakarta, 2010.

[5] A.D. Nastiti, Perkembangan Cloud Computing di Indonesia, Waena, 2010.

[6] F. Thia, Kenapa Komputasi Awan, http://blog.komputasiawan.com/2008/05/kena pa-komputasi-awan.html, 2008, retrieved April 16, 2011.

[7] R. Sofyan, Mengenal Teknologi Cloud Computing, www.view-codes.com, 2010, retrieved April 16,2011

[8] B. Ranti, "Identification of Information Systems/Information Technology Business Values with Hermeneutic Approach: Cases in Indonesia," Ph.D Thesis, Faculty of Computer Science, Universitas Indonesia, Indonesia, 2008.

[9] Y.R.P. Chritism, "Pengaruh Economic Value Added Terhadap Harga Saham (Studi Kasus Perusahaan Yang Tergabung Dalam Index LQ45)," B.S Thesis, Faculty of Economic, University Gunadarma, Indonesia, 2010. 